\title{
The Relationships between Work Values and Work-Related Attitude: The Role of Social Support as Moderator
}

\author{
${ }^{*}$ Nor A'tikah Mat Ali*a, Siti Aisyah Panatik ${ }^{b}$ \\ Universiti Teknologi Malaysia, Malaysia \\ *atikah2211@gmail.com
}

\begin{abstract}
In organizational context, work values play an important role to enhance work attitudes and performance. Previous study stated that there are two types of prominent work values in organization, which are intrinsic and extrinsic values. Both of these work values will influence work attitude, such as job satisfaction and job involvement. Numerous of the prior literatures indicated that there is a positive correlation between work values and the work-related attitude among employees in organization. Thus, this paper aims to provide a review on the relationship between work values and work attitudes in order to get better understanding on the effects of work values in organization. Furthermore, this paper also proposes the potential role of social support as moderator in the relationship between work values and work attitude. This paper contributes to the knowledge in terms of the implication of work values in organization based on the literature review perspective. This paper also discusses the recommendation for future study in this field.
\end{abstract}

Key words: Work values, intrinsic values, extrinsic values, work attitude, social support

\section{Introduction}

Values play an important role in individual life as well as among employees in organization. According to Rokeach (1973), values related to the human needs and desire towards any situation that happen in their life. Value also involves the concepts and beliefs that will affect emotions and attitudes, any situation, and guiding the selection and assessment of human behaviour (Ucanok, 2008). In organization, work values become an interesting topic among the researchers in order to investigate work-related behaviour among employees (Ying \& Aaron, 2010) such as job satisfaction and job involvement. Employees are considered to be the important assets of organization to success. Therefore, efforts from the Human Resource Department to understand and analyze the work values aspects which affect the performance of the employees is a basic necessity to ensure effectiveness and efficiency (Krishnan \& Mary, 2012). In organization, employees usually understand the world of work as it relates to making money (Mahamuda Parvin \& Nurul Kabir, 2011). However, previous research regarding the factor that influences employee satisfaction found that there are many other aspects of work contribute to their satisfaction besides money. Some of the reason are including work values that focusing on individual productivity, esteem, financial, economic security and contribution to society among them (Adeyinka, Ayeni, \& Popoola, 2007; Ducharme \& Martin, 2000; Froese \& Xiao, 2012). Work values become one of the important factors that have a great influence on the career choice and the fulfilment of values that related to job satisfaction (Hegney, Plank, \& Parker, 2006). This is because some of the employees perceive their job not only for money but as an opportunity to use and improve their skill, enhance their esteem, financial security and contribute to the society which are something that reflect their personal interest (Judge, Piccolo, Podsakoff, Shaw, \& Rich, 2010; Lim, 2010).

\section{Literature Review}

Overview of Work Values in Organization: Work values are one of the subset of overall human values (Liu\&Lei, 2012). Work values act as common values that are always being discussed relating to the employees development and achievement in their workplace. In organization, work values can function as evaluative standards that people use to interpret their work experiences and determine the meaning that individuals attribute to work, jobs, organizations, specific events and conditions (Ucanok, 2008). The impact of work values on work-related attitudes become an interesting topic among researchers (ChinChih, 2006). Based on the review of the previous research in this area, most of the researchers have their 
own understanding and definition to explain work values among employees in organization. Super (1990) highlighted that there are fifteen dimensions of work values that had been investigated based on the Work Values Inventory which are altruism, aesthetics, creativity, intellectual stimulation, achievement, independence, prestige, management, economic returns, security, surrounding, supervisory relations, association, way of life and lastly is variety. Then, some researchers divided these fifteen dimensions of work values into three categories, which are intrinsic (terminal values), extrinsic (instrumental values) and concomitant values (Robinson \& Betz, 2008). However, some of the researchers argued that there are only two common types of work values among employees, which are intrinsic, and extrinsic work values (Chin-Chih, 2006). Thus, this paper will discuss the work values based on these two dimensions: intrinsic and extrinsic work values.

Intrinsic work values: Intrinsic (terminal) values refer to the degree, which an individual enhance, their personal growth, used their external talent, enhance creativity, and improve quality of life during the courses of their work (Chin-Chih, 2006). Intrinsic work values also refer to the individual internal factor or self-actualization gained from working, contributing to society and having meaningful work (Parboteeah, Paik, \& Cullen, 2009). Intrinsic work values directly express employee's openness to change their value that related to the pursuit of autonomy, interest, growth, and creativity in work. Employees might also seek out challenging tasks that allow them to develop new skills and enhance values that satisfying their need and desire.

Extrinsic work values: Extrinsic (instrumental) values refer to the degree of important which an individual try to obtain the level of excellence in social interaction, getting a harmonious social relationship, freedom and try to achieve a balance between services within the organizational systems. It also involved the important of holistic environment to fulfil their sense of security and maintain their needs while they are working (Chin-Chih, 2006). Extrinsic work values is also similar to the instrumental values which are focusing on external outcomes pertaining to the job and include work benefit, work security and less demanding work (Parboteeah, et al., 2009). Employees in organization try to satisfy their extrinsic values of work such as job security and income provided by organization with the requirements needed for general security and maintenance of order in their lives. Chin-Chih (2006) mentioned that intrinsic values consisted of three dimensions, which are self-growth tendency, selfrealisation tendency and self-esteem tendency. Meanwhile, the extrinsic work values comprised of four dimensions, which are social interaction tendency, organizational security and economic benefits tendency, stability and anxiety-free tendency, lastly are reaction, health, and transport tendency. The detail description of each of the values as stated in Table 1 :

Table 1: Work Value Dimensions by Chin-Chih (2006)

\begin{tabular}{|c|c|c|}
\hline $\begin{array}{l}\text { Type of Work } \\
\text { Values }\end{array}$ & Dimension & Detail \\
\hline \multirow[t]{3}{*}{ Intrinsic Values } & Self-growth tendency & $\begin{array}{l}\text { The degree of important which an individual } \\
\text { focusing on obtain new knowledge, enhance self- } \\
\text { growth, creativity and encourage personal } \\
\text { development during their work. }\end{array}$ \\
\hline & Self-realization tendency & $\begin{array}{l}\text { The degree of important which an individual aims } \\
\text { to fulfilling their lifelong goals, request of personal } \\
\text { talent, improving quality of life and enhancing } \\
\text { their social welfare during their work. }\end{array}$ \\
\hline & Self-esteem tendency & $\begin{array}{l}\text { The degree of important which an individual } \\
\text { focusing on personal achievement, self-recognition } \\
\text { and autonomy, getting respect from members and } \\
\text { senior management during their work. }\end{array}$ \\
\hline \multirow[t]{2}{*}{ Extrinsic Values } & Social Interaction tendency & $\begin{array}{l}\text { The degree of important which an individual's } \\
\text { focusing on enhance the social interaction and } \\
\text { sharing their daily emotional experiences with } \\
\text { members and superiors, and creating harmonious } \\
\text { social relations with others their work. }\end{array}$ \\
\hline & $\begin{array}{l}\text { Security and economic } \\
\text { tendency }\end{array}$ & $\begin{array}{l}\text { The degree of important which an individual } \\
\text { places on achieve reasonable economic security } \\
\text { through organizational system and satisfied their }\end{array}$ \\
\hline
\end{tabular}


Stability and Freedom form Anxiety tendency

Recreation, health transport tendency sense of security during their work.

The degree of important which an individual's try to perform their job without tension, anxiety or fear.

and The degree of important which an individual's places on reach enough physical energy, healthy and availability of convenient traffic transport options during their work.

Source: Chin-Chih (2006).

Both intrinsic and extrinsic work values must fulfil employees' needs, desires in order to enhance organizational, and employees' performance. Some of the intrinsic values such as enhancing the selfgrowth tendency have a significant relationship with organizational performance (Glazer, Daniel, \& Short, 2004). In addition, extrinsic values such as reward and economic security play an important role to affect work attitude among employees in organization. Rewards given by organization become an important value that enhances feeling of secure among employees during their work. Employees will work hard because they expect the suitable rewards from the organization such as salary raises and promotions (Liao, Lu, Huang, \& Chiang, 2012).

The Relationship between Work Values and Work-Related Attitude: Previous research in personorganizational fit study suggested that there is a positive correlation between work values and workrelated attitudes (Froese \& Xiao, 2012). This relationship is also supported by Herzberg and Maslow theories which explain the important of hygiene factors (instrumental value) and motivators factors (terminal values) to help improving individual satisfaction, affective commitment and job involvement. In the context of organizational behaviour, most of the studies related to work attitude mentioned that job satisfaction and job involvement as the components of work-related attitude (Liao, et al., 2012).

Work Values and Job satisfaction: According to Kubat and Kurrrzum (2009), work values are defined as beliefs, attitudes, preferences and interests about work that are related to the job satisfaction. Job satisfaction is a result of employee's perception of how well their job provides those things that are viewed as important (Adeyinka, et al., 2007). Job satisfaction can be defined as an employee's reaction towards outcome of their work either it is satisfied or not (Hong Lu, While, \& Barriball, 2005). When the organization fulfil the employees' needs and desires based on the extrinsic values, employee will enhance the psychological satisfaction, such as feeling valuable, helping organizational to achieve the goals and expressing their talents in working (Adeyinka, et al., 2007). A study by Frieze, Olson, Murrell and Selvan (2006) found that the effort of management to emphasis work values (e.g salary) as an important in organisation increases the satisfaction level among employees. Their research was conducted among 800 MBA students. Furthermore, another research that investigated the relationship between work values and job satisfaction among nurses indicated that intrinsic and extrinsic work values enhanced job satisfaction and reduced intention to leave among nurses (Hegney, et al., 2006). The latest research regarding this topic conducted by Froese and Xiao (2012) also found that there are significant relationship between work values and job satisfaction. This study had been conducted among 500 whitecollar employees who are employed by foreign invested companies in China.

Work Values and Job involvement: Job involvement was linked with an individual commitment, hardworking and concern about his career (Mohsan, et al., 2011). Job involvement refers to the degree which an employee identifies his job, actively participate in it, and consider his job performance is important to his self-worth that may be influenced by their satisfaction on intrinsic or extrinsic needed (Bhatia, Deep, \& Sachdeva, 2012). Previous researchers found that work values have a significant relationship with job involvement. For example, Chin-Chih (2006) investigated the relationship between work values, job involvement and organizational commitment among 1047 nurses in Taiwan. The finding of this research showed that work values positively related to job involvement. In addition, research by Lim (2010) among 92 employees of packaging industry in Penang also showed that intrinsic work values positively and significantly related to job involvement. Additionally, the study from Feather and Rauter (2004) towards 101 regular teachers and 53 temporary teachers from Victoria, Australia found that instrumental value (ex. job security) was positively related to job involvement. 
The Role of Social Support in Organization: Social support can be defined as an experience that an individual is valued, respected, cared and loved by others who are present in his life (Md Aris Safree \& Mariam Adawiah, 2012).In organizational context, social support refers to helpful functions performed for an individual by other such as supervisors and co-workers (Panatik, 2010). These functions typically include social-emotional aids, instrumental aid, informational aids and social integration (Panatik, 2010). Social support is important because it has beneficial effects on well-being. Social support plays an important role in organization in terms of workgroup interaction that involves employees, their supervisor and co-workers. Social support in this study is divided into two types, which are supervisor support and co-worker support. According to Salimi (2010), supervisor support refers to the supervisor's ability to strengthen and support employees through the process of learning in the workplace. Meanwhile, co-worker support refers to the other employees help and guidance in the organization during carrying out duties in the workplace (Cromwell \& Kolb, 2004). Supervisor and co-worker support are likely to influence the formation of positive values, which in turn will increase job satisfaction and job involvement. Workgroup interactions, especially social support received from co-worker and supervisor may significantly contribute to positive work attitudes such as job satisfaction and job involvement. As stated by Ducharme and Martin (2000), social support may have significant contribution to job satisfaction. In addition, research by Parvin and Kabir (2011) also suggested that supervision and co-worker relation are the most important factors contributing to job satisfaction.

In this paper, the researcher will propose the potential role of social support as moderator in the relationship between work values and work attitude among employees in organization. According to Salkind (2009), moderator variables refer to the variables that can affect a decrease or increase relationship between the two variables of the study. In this present research, moderator variables (supervisor and co-worker support) are used by researchers to see changes between the predictor variable (work values) and dependent variables (job satisfaction and job involvement). In organization, support from supervisor and co-worker can enhance employees motivation towards their work. Perceived support from supervisor and co-worker enhance high quality working relationship and help employees to feel that other organizational member care for them. Additionally, previous organizational researchers also have mentioned that social support in organization can influence employee's positive feeling, work attitude and behavioural intentions (Cropanzano \& Mitchell, 2005). In terms of enhancing positive work attitude, social support promotes high job satisfaction and job involvement when supervisor and co-worker provide task-based assistance, information and emotional support. In the context of this study, the presence of supervisor and co-workers support may be able to reduce or increase the value of the work, which in turn influences the increasing or decreasing job satisfaction and job involvement.

The role of social support as moderator variable also had been supported by Social Exchange Theory (Blau, 1964). Based on the Social Exchange Theory, social support helps to buffer the effect of work values especially terminal and instrumental values on work-related attitudes such as job satisfaction and job involvement. This theory also explains the mutual relationship between employee and organization that lead to the buffer effect, which is not only focusing on reward but also involves the emotional and social aspects (Cromwell \& Kolb, 2004; Tek-Yew, 2009). Thus, the researchers expect that social support is likely to be one of emotional and social factors within the organization that will influence mutual relationship between employees and organization. In additions, previous studies also indicated that good support and guidance from supervisor and co-worker would enhance employee satisfaction and involvement in their job (Chin-Chih, 2006; Cohen, 2010; Froese \& Xiao, 2012). Based on the review from previous research, this study proposes the potential role of social support (supervisor and co-worker support) as a moderating variable in the relationship between work values and work-related attitude.

A Synthesize and Agenda for Future Research: This paper provides empirical evidence about positive effects of work values in enhancing work attitudes such as job satisfaction and job involvement in organization. This paper aims to suggest that there is a need of empirical evidence of this relationship from Malaysian perspective. As a high power distance and collectivism cultural values country, Malaysia always promote a good relationship among employees that show the best work values such as altruism, associates and good supervisory relationships. In high power distance culture, supervisors are expected to monitor their subordinates to enhance their need and desires on the intrinsic values such as enhancing their self-achievement. Besides that, Malaysia as a collectivism and high power distance country that practices altruism values and supervisory relationship also can help employees to fulfil their social 
interaction in organization. The organization that emphasizes the important role of social support can help enhance job satisfaction and involvement among employees, which in turn improve organizational performance (Krishnan \& Mary, 2012).

This paper also provided evidence that support the potential role of social support as moderator in the relationship between work values and work attitudes. Based on the past literatures, the current paper will proposes the potential role of social support (supervisor and co-worker support) as moderator variables in the future study. The researchers predict that supervisor and co-worker support will enhance the relationship between work values and work attitudes, especially among employees in Malaysia. This conceptual paper will extend the model and theories from the previous research related to the work values. This paper provides a conceptual model of work values, which integrates the work values as predictor, social, support as moderator and work attitudes as outcomes variables as can be seen in Figure 1. The present paper expects that social support will also play as the moderator in the relationship between work values and work attitude (job satisfaction and job involvement) among Malaysian employees in organization.

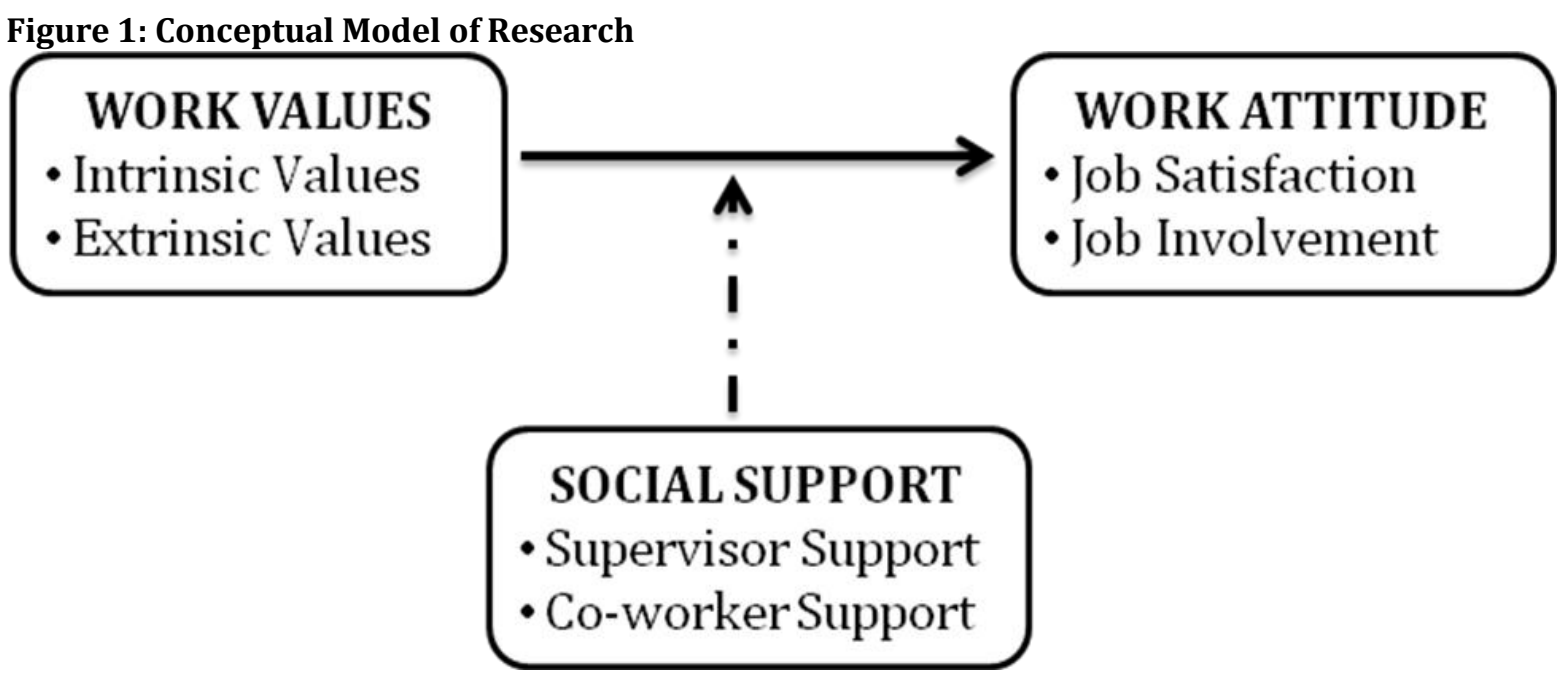

As recommendations for future research, even though previous research had tested the impact of work values on work attitudes, it will be more interesting if future research can modify and expand the model of work values in organization by including some of other potential moderator variables to see its impact on employees' behaviour. Therefore, the current study will proposes the moderator role of social support in the relationship between work values and work attitude among the employees in Malaysia perspectives.

General Discussion: The review from the previous research indicated the importance of intrinsic and extrinsic work values and their consequences on work attitude such as job satisfaction and job involvement. Prior researchers highlight that there are two types of work values that are prominent at workplace, namely intrinsic and extrinsic work values. The previous literatures stated that work values that fulfil the employees' need and desire enhance job satisfaction, job involvement and indirectly help the organizational achievement. Apart from that, social support from supervisor and co-worker also play an important role to promote positive work attitude among employees. As a positive role in organization, supervisor and co-worker support could potentially increase work values, increase job satisfaction, and job involvement. The literature reviews provide an overview of the role social support as a moderator in the relationship between work values and work-related attitude. The present paper provides significant information pertaining to the relationship between work values and work attitude such as job satisfaction and job involvement among employees in organization. This paper clearly highlighted that there were significant positive relationship between work values and work attitudes. Previous literature on social support also supports the potential role of social support as moderator variables in the relationship between work values and work attitudes. Organization and employees should be aware of the importance of work values and promote the social support from supervisor and co-worker in order to increase work values and work attitudes among employees at workplace. 


\section{Conclusion}

In conclusion, positive work values among employees in organization are important in increasing job satisfaction and job involvement. Giving more attention on work values will help organization in developing the human resource management system that is able to attract, as well as enhance job satisfaction and job involvement among employees (Froese \& Xiao, 2012). Additionally, supervisor and co-worker support in the organization could potentially increase work values, increase job satisfaction, and job involvement. In this study, researchers expect that support from supervisors and co-workers will help employees in increasing their work values. From a practical perspective, identification of social support as a moderator is important to enhance the relationship between work values and work attitude (job satisfaction and job involvement) among the employees which in turn will contribute to enhance organizational effectiveness (Diefendorff, Brown, Kamin, \& Lord, 2002).

\section{References}

Adeyinka, T., Ayeni, C. O. \& Popoola, S. O. (2007). Work Motivation, Job Satisfaction, and Organisational Commitment of Library Personnel in Academic and Research Libraries in Oyo State, Nigeria. Library Philosophy and Practice 2007, 1-16.

Bhatia, A., Deep, G. \& Sachdeva, S. (2012). Analyzing the Role of Job Involvement on Organizational Effectiveness: An Empirical Study among the Employees Of Punjab National Bank. International Journal Of Computing \& Business Research, Proceedings Of 'I-Society 2012' at GKU, Talwandi Sabo Bathinda (Punjab), ISSN (online): 2229-6166.

Chin-Chih, H. (2006). A Study of the Relationship between Work Values, Job Involvement and Organisational Commitment among Taiwanise Nurses. Queensland Universoty of Technology: Australia.

Cohen, A. (2010). Values and Commitment: A Test of Schwartz Human Values Theory among Arab Teachers in Israel. Journal of Applied Social Psychology, 40(8), 1921-1947.

Cromwell, S. E. \& Kolb, J. A. (2004). An Examination of Work-Environment Support Factors Affecting Transfer of Supervisory Skills Training to the Workplace. Human resource Development Quarterly, 15(4), 449-472.

Cropanzano, R. \& Mitchell, M. S. (2005). Social Exchange Theory: An Interdisciplinary Review. Journal of Management, 31, 874-900.

Diefendorff, J. M., Brown, D. J., Kamin, A. M. \& Lord, R. G. (2002). Examining the Roles of Job Involvement and Work Centrality in Predicting Organizational Citizenship Behaviors and Job Performance. Journal of Organizational Behavior, 23, 93-108.

Ducharme, L. J. \& Martin, J. K. (2000). Unrewarding Work, Coworker Support and Job Satisfaction: A Test of the Buffering Hypothesis. Work and Occupations, 27(2), 223-243.

Feather, N. T. \& Rauter, K. A. (2004). Organizational Citizenship Behavior in Relation to Job Status, Job Insecurity, Organizational Commitment and Identification, Job Satisfaction and Work Values. Journal of Occupational and Organizational Psychology, 77, 81-94.

Frieze, I. H., Olson, J. E., Murrell, A. J. \& Selvan, M. S. (2006). Work Values and Their Effect on Work Behavior and Work Outcomes in Female and Male Managers. Sex Roles, 54(1/2), 83-93.

Froese, F. J. \& Xiao, S. (2012). Work Values, Job Satisfaction and Organizational Commitment In China. The International Journal of Human Resource Management, 23(10), 2144-2162.

Glazer, S., Daniel, S. K. \& Short, K. M. (2004). A Study of the Relationship between Organizational Commitment and Human Values in Four Countries. Human Relations, 57, 323-345.

Hegney, D., Plank, A. \& Parker, V. (2006). Extrinsic and Intrinsic Work Values : Their Impact on the Job Satisfaction In Nursing. Journal of Nursing Management, 14(4), 271-281.

Hong Lu, While, A. E. \& Barriball, K. L. (2005). Job Satisfaction among Nurses: A Literature Review. International Journal of Nursing Studies, 42, 211-227.

Judge, T. A., Piccolo, R. F., Podsakoff, N. P., Shaw, J. C. \& Rich, B. L. (2010). The Relationship between Pay and Job Satisfaction: A Meta-Analysis of The Literature. Journal Of Vocational Behavior, 77, 157167.

Koivula, N. (2008). Basic Human Values in the Workplace. Department of Social Psychology, University of Helsinki: Helsinki.

Krishnan, J. \& Mary, S. V. (2012). Perceived Organizational Support: An Overview on Its Antecedents and Consequences. International Journal of Multidisciplinary Research, 2(4), 1-13. 
Kubat, U. \& Kuruuzum, A. (2009). An Examination of the Relationship between Work Values and Personality Traits in Manufacturing Industry. International Journal of Business And Management, $1(1), 37-48$.

Liao, S. W., Lu, C. Y., Huang, C. K. \& Chiang, T. L. (2012). Work Values, Work Attitude and Job Performance of Green Energy Industry Employees in Taiwan. African Journal of Business Management, 6(15), 5299-5318.

Lim, C. T. (2010). Relationship between Work Values and Job Involvement: A Study Among Manufacturing Operators in the Packaging Industries in Penang. Universiti Sains Malaysia: Penang.

Mahamuda Parvin, M. \& Nurul Kabir, M. (2011). Factors Affecting Employee Job Satisfaction of Pharmaceutical Sector. Australian Journal of Business and Management Research, 1(9), 113-123.

Md Aris Safree, M. Y. \& Mariam Adawiah, D. (2012). The Relationship between Social Support and Psychological Problems among Students. International Journal Of Business And Social Science, 1(3), 110-116.

Mohsan, F., Musarrat Nawaz, M., Khan, M. S., Shaukat, Z., Islam, T. \& Aslam, N. (2011). Impact of Job Involvement on Organizational Citizenship Behavior and in-Role Job Performance : A Study on Banking Sector Pakistan. European Journal of Social Science, 24(4), 494-502.

Panatik, S. A. (2010). Impact of Work Design on Psychological Work Reactions and Job Performance among Technical Workers: A Longitudinal Study in Malaysia. University of Waikato, Hamilton.

Parboteeah, K. P., Paik, Y. \& Cullen, J. B. (2009). Religious Groups and Work Values: A Focus on Buddhism, Christianity, Hinduism and Islam. International Journal of Cross Cultural Management, 9(1), 51-67.

Robinson, C. H. \& Betz, N. E. (2008). A Psychometric Evaluation of Super's Work Values Inventory-Revised. Journal of Career Assesment, 16(4), 456-473.

Rokeach, M. (1973). The Nature of Human Values. New York: Free Press.

Salkind, N. J. (2009). Exploring Research. New Jersey: Pearson Prentice Hall.

Salimi, S. O. (2010). Mentoring and Work Attitude among Nurses: The Moderator Roles of Gender and Social Support. European Journal of Psychology(1), 102-126.

Super, D. E. (1990). A Life-Span, Life Space Approach to Career Development. San Francisco: Jossey-Bass.

Tek-Yew, L. (2009). The Relationships between Perceived Organizational Support, Felt Obligation, Affective Organizational Commitment and Turnover Intention of Academics Working with Private Higher Educational Institutions in Malaysia. European Journal of Social Sciences, 9(1), 7287.

Ucanok, B. (2008). The Effects of Work Values, Work-Value Congruence and Work Centrality on Organizational Citizenship Behavior. Academy of Science, Engineering and Technology, 46, 156169.

Ying, L. \& Aaron, C. (2010). Values, Commitment, and OCB among Chinese Employees. International Journal of Intercultural Relations, 34, 493-506.

Ying, L. \& Yong, L. (2012). The Connotation of Work Values: A preliminary Review. Asian Social Science, $8(1), 47-53$. 